\title{
PENGEMBANGAN PERPUSTAKAAN JURUSAN
}

\author{
Rugaiyah
}

\begin{abstract}
The main objective of this study is to describe the development of the library in the Educational Management Department, School of Education, State University of Jakarta. The study covers the availability and utilization of the library facility, the library service, and the consumers' satisfaction. The study was conducted at The Education Management Department for four months with 72 samples selected randomly. The study found out the library of the Education Management Department has been well managed, the library facility is satisfactory but the capacity can accommodate about 20 students only. The consumers' satisfaction tends to be low.
\end{abstract}

Key words: library, library utilization, library consumers, consumers satisfaction

\section{Abstrak}

Tujuan utama dari penelitian ini adalah untuk menjelaskan bagaimana pengembangan perpustakaan jurusan Manajemen Pendidikan, meliputi aspek: (1) ketersediaan dan pemanfaatan fasilitas perpustakaan, (2) layanan pelanggan perpustakaan, (3) kepuasan pelanggan terhadap layanan perpustakaan. Penelitian ini dilakukan di jurusan Manajemen Pendidikan dalam waktu 4 bulan dengan jumlah sampel 72 responden yang dilakukan dengan acak sederhana. Hasil penelitian menunjukkan bahwa perpustakaan jurusan Manajemen Pendidikan tidak dikelola dengan baik. Ketersediaan fasilitas sudah cukup tetapi ruangan dapat menampung hanya sekitar 20 siswa dan kepuasan pelanggan untuk layanan yang disediakan atau kelengkapan bahan pustaka masih rendah.

Kata-kata kunci: perpustakaan, pemanfaatan perpustakaan, pelanggan perpustakaan, kepuasaan pelanggan.

\section{PENDAHULUAN}

\section{Latar Belakang Masalah}

Perpustakaan memiliki peran dan manfaat yang sangat penting dalam mengembangkan sebuah institusi pendidikan. Keberadaan perpustakaan dapat dijadikan sebagai wahana belajar sepanjang hayat, dapat mengembangkan potensi masyarakat, dapat dijadikan sebagai salah satu upaya untuk memajukan kebudayaan nasional, dan dapat dijadikan sebagai wahana pelestarian kekayaan budaya bangsa. Selain itu, dalam rangka meningkatkan kecerdasan kehidupan bangsa maka perlu ditumbuhkan budaya gemar membaca melalui pengembangan dan pendayagunaan perpustakaan sebagai sumber informasi yang berupa karya tulis, karya cetak, dan atau karya rekam.

Secara eksplisit dalam undang-undang Nomor 43 tahun 2007 disebutkan bahwa perpustakaan merupakan institusi pengelola koleksi karya tulis, karya cetak, dan/atau karya rekam secara profesional dengan sistem yang baku guna memenuhi kebutuhan pendidikan, penelitian, pelestarian, informasi, dan rekreasi para pemustaka dengan tujuan untuk memberikan layanan kepada pemustaka, untuk meningkatkan kegemaran membaca, serta memperluas wawasan dan pengetahuan untuk mencerdaskan kehidupan bangsa.

Mengingat pentingnya keberadaan perpustakaan, maka dari itu perpustakaan merupakan salah satu sarana yang harus disiapkan untuk mahasiswa. Untuk itu, pengelolaan perpustakaan harus memberikan layanan yang bermutu. Dengan layanan tersebut setiap mahasiswa dapat menggali berbagai pengetahuan sekaligus membantu meningkatkan kualitas proses belajar mengajar. Di samping sebagai sentral kegiatan belajar mengajar, perpustakaan juga dapat dijadikan sebagai pengganti dan fungsi lembaga pendidikan itu sendiri, maka sudah sepantasnya penggunaan perpustakaan diperhatikan secara serius.

Manfaat perpustakaan dapat secara langsung dirasakan bagi para pengguna perpustakaan. Para 
mahasiswa akan terbantu dalam pengembangan wawasan keilmuannya dan para dosen pun dapat menambah berbagai informasi yang dibutuhkan.

Akan tetapi, kondisi perpustakaan jurusan belum dioptimalkan oleh seluruh pihak, ini disebabkan oleh berbagai faktor, di antaranya kurangnya sumber daya manusia yang mampu mengelola perpustakaan dengan serius dan minimnya dana untuk pengelolaan perpustakaan. Minimnya dana menyebabkan sulitnya menyediakan fasilitas yang lebih memadai. Baik untuk melengkapi buku-buku perkuliahan, buku-buku pengetahuan umum, majalah, buletin, koran, dan lain-lain. Dengan kondisi demikian dapat diprediksikan minat mahasiswa untuk pergi ke perpustakaan sangat minim.

Dengan demikian, perpustakaan sebagai sarana dalam penunjang pembelajaran harus mendapat perhatian dari semua pihak baik mengenai pengalokasian dana bagi kebutuhan perpustakaan, pemberian pelatihan, maupun penyiapan SDM di dalamnya.

Melihat kondisi perpustakaan yang pengelolaannya belum optimal, maka pihak jurusan mencoba merespon dan mencari akar permasalahan serta mencari solusi dari permasalahan yang ada. Diharapkan dengan dilaksanakannya penelitian ini dapat memberikan masukan dalam pembenahan perpustakaan jurusan dan hal-hal apa saja yang perlu diperbaiki dalam mengelola perpustakaan.

Berdasarkan latar belakang masalah di atas, maka dirumuskan masalah sebagai berikut “Bagaimanakah pengembangan perpustakaan jurusan manajemen pendidikan yang ditinjau dari aspek ketersediaan sarana dan pemanfaatan bahan pustaka, layanan pustaka, dan kepuasan stakeholders?

Penelitian ini bertujuan untuk mengetahui tentang pengembangan perpustakaan jurusan Manajemen Pendidikan yang ditinjau dari: (1) ketersediaan sarana pemanfaatan bahan pustaka; (2) layanan pustaka jurusan Manajemen Pendidikan; (3) kepuasan stakeholders terhadap layanan perpustakaan jurusan Manajemen Pendidikan

Hasil penelitian diharapkan dapat mengetahui tingkat kepuasan mahasiswa terhadap pelayanan perpustakaan di jurusan Manajemen Pendidikan, yang diharapkan dapat dijadikan sebagai suatu acuan untuk melakukan perbaikan dalam meningkatkan mutu pelayanan perpustakaan. Di samping itu, diharapkan ke depannya, perpustakaan jurusan MP dapat dijadikan sebagai laboratorium untuk pengembangan perpustakaan-perpustakaan yang ada di sekolah-sekolah.

\section{KAJIAN TEORETIS}

\section{Pengertian Perpustakaan}

Perpustakaan merupakan suatu unit kerja dari suatu badan atau lembaga yang mengelola bahanbahan pustaka, baik perupa buku-buku maupun nonbuku yang diatur secara sistematis menurut aturan tertentu sehingga dapat dipergunakan sebagai sumber infomasi oleh setiap pemakainya. (Bafadol, 2001:3). Perpustakaan dapat diartikan sebagai unit kerja, tempat mengumpulkan, menyimpan dan mengelola bahan pustaka, bahan pustaka tersebut dikelola secara sistematis dengan sistem tertentu, dan sebagai sumber informasi bagi setiap pemakainya. Pendapat lain menjelaskan perpustakaan adalah koleksi yang terdiri dari bahan-bahan tertulis, tercetak, ataupun grafis lainnya seperti film, slide, piringan hitam, dan tape dalam sebuah ruangan atau gedung yang diatur dan diorganisasikan dengan sistem tertentu, agar dapat digunakan untuk keperluan belajar, penelitian, pembacaan, dan sebagainya (Sumadji, 1992:13).

Untuk dapat dikatakan sebagai perpustakaan menurut Ignatius, minimal ada empat syarat yang harus dipenuhi, yaitu: (1)ada masyarakat yang akan menggunakan perpustakaan tersebut; (2) memiliki bahan pustaka yang dapat memenuhi kebutuhan masyarakat; (3)memiliki gedung atau ruang dan fasilitas lainnya sebagai tempat penyimpanan bahan pustaka serta tempat membaca dari para pengunjung; serta (4)memakai sistem manajemen yang baik untuk mengatur bahan pustaka kepada masyarakat (Ignatius, 1990;22-23)

Dari penjelasan di atas, perpustakaan dapat diartikan sebagai kumpulan koleksi bahan pustaka yang diatur secara sistematis dalam suatu ruang yang dapat digunakan oleh mahasiswa dan dosen dalam menunjang proses perkuliahan. Adapun yang dimaksud dengan masyarakat pengguna perpustakaan adalah para mahasiswa dan dosen, bahan-bahan pustaka yang memenuhi persyaratan kebutuhan mahasiswa dapat berbentuk buku-buku yang relevan dengan materi perkuliahan, buku-buku pengetahuan umum dan hiburan, lukisan, kaset, film, dan lain-lain.

\section{Pengelolaan Perpustakan}

Pengelolaan perpustakaan adalah bentuk pelayanan bagi peminat dalam hal ini mahasiswa. Bentuk-bentuk pelayanan tersebut meliputi.

a. Pelayanan Pembaca

Pelayanan pembaca menjadi tolok ukur bagi keberhasilan kerja pustakawan, namun tugas layanan tidak mungkin berdiri sendiri tanpa didukung oleh 
tugas pembinaan koleksi, yang menyangkut pengadaan, pengolahan, dan pemeliharaan koleksi. b. Pelayanan Peminjaman

Pelayanan peminjaman adalah kegiatan kerja berupa pemberian bantuan kepada pemakai perpustakaan dalam proses peminjaman dan pengembalian koleksi pustaka. Kegiatan ini sering disebut dengan sirkulasi. Sirkulasi dalam arti mengedarkan koleksi perpustakaan kepada pemakainya. Pustakawan harus pandai menentukan kebijakan dalam mengatur pelayanan yang disesuaikan dengan situasi dan kondisi perpustakaan, antara lain.

1) Ruang perpustakaan kecil dan jumlah koleksi terbatas, namun merupakan sumber informasi mutakhir, situasi ini dapat diatasi dengan membuat persyaratan peminjaman yang dapat menjamin pustaka tidak hilang.

2) Terbatasnya jumlah tenaga perpustakaan. Situasi ini dapat diatasi dengan membatasi waktu pelayanan, misalnya tidak setiap hari atau sehari hanya beberapa jam (tidak selama jam kerja) (Soeatminah, 1991: 139)

c. Pelayanan referensi dan informasi

Referensi berasal dari bahasa inggris "to refer" yang artinya menunjuk kepada. Apapun yang ditunjuk baik orang maupun benda sebagai sumber jawaban pertanyaan informasi disebut referensi. Akan tetapi, referensi dibatasi pada informasi yang terekam, seperti buku, majalah, jurnal, buletin dan lain-lain. Pelayanan referensi merupakan pelayanan langsung berupa pemberian bantuan kepada siswa, bantuan tersebut berupa jawaban atas pertanyaan-pertanyaan dengan menggunakan koleksi referensi petugas referensi dituntut memiliki kecakapan dalam menganalisis pertanyaan sehingga diharapkan mampu menjawab pertanyaan dengan cepat, tepat, dan benar.

\section{Prinsip-Prinsip Pustakawan}

Jika pustakawan ingin memperoleh kemajuan dalam bidang tugasnya, maka pustakawan harus menjadikan perpustakaan sebagai sarana belajar bagi pembacanya. Adapun prinsip-prinsip pustakawan adalah sebagai berikut (1)seorang pustakawan haruslah orang yang berpendidikan; (b)seorang pustakwan adalah seorang pendidik; (3)peranan seorang pustakawan menjadi penting bila peranannya dipadukan dalam sistem sosial politik yang berlaku di sekitarnya; (a) tugas pustakawan adalah menambah koleksi perpustakaan (basuki, 1993:31)

Dengan adanya prinsip-prinsip pustakawan tersebut maka seorang petugas perpustakaan harus benar-benar menjalankan fungsi dan tanggung jawabnya agar kegiatan dalam perpustakaan dapat berjalan dengan lancar.

\section{Tujuan Perpustakaan}

Perpustakaan dapat digolongkan sebagai sarana atau perangkat dari lembaga pendidikan formal. Adapun tujuan perpustakaan adalah membantu untuk mencapai tujuan khusus dan tujuan pendidikan pada umumnya. Tujuan khusus adalah untuk membantu mencapai tujuannya sesuai dengan kebijakan lembaga tempat perpustakaan tersebut bernaung (basuki, 1993:51), sedangkan menurut Ahmad, (1987:9) menjelaskan tujuan perpustakaan sebagai berikut (1) untuk menimbulkan, menanamkan serta membina minat mahasiswa membaca, sehingga menjadi suatu kebiasaan bagi agar membaca menjadi kegemaran; (2) untuk memperluas horison pengetahuan mahasiswa dengan menyediakan berbagai bukubuku pengetahuan; dan (3) ikut membantu mahasiswa ke arah self study.

Dengan memperhatikan pendapat di atas maka dapat dikatakan bahwa pengelolaan perpustakaan yang baik dapat menumbuhkan minat belajar siswa yang pada akhirnya diharapkan mutu belajar siswa akan mengalami peningkatan yang berarti.

\section{Manfaat Perpustakaan}

Dengan adanya perpustakaan diharapkan dapat membantu stakeholders dalam menyelesaikan tugas dalam perkuliahan. Perpustakaan akan bermanfaat apabila benar-benar dapat digunakan secara optimal dan dapat mendukung tujuan perkuliahan. Adapun manfaat perpustakaan adalah.

a. Dapat menimbulkan kecintaan mahasiswa untuk membaca.

b. Dapat memperkaya pengalaman belajar mahasiswa.

c. Dapat menanamkan kebiasaan belajar mandiri.

d. Dapat mempercepat proses penguasaan teknik membaca.

e. Dapat membantu mahasiswa bertanggung jawab.

f. Dapat memperlancar mahasiswa dalam menyelesaikan tugas-tugas perkuliahan.

g. Dapat membantu mahasiswa menemukan sumber belajar.

h. Dapat membantu stakeholders dalam mengikuti perkembangan IPTEK

\section{Fungsi Perpustakaan}

Selain memberi manfaat, perpustakaan pun memiliki fungsi-fungsi sebagai berikut:

\section{a. Fungsi Edukatif}

Perpustakaan berfungsi sebagai salah satu sarana penunjang belajar. Para mahasiswa dapat 
menggunakan bahan-bahan pustaka yang tersedia untuk menambah ilmu.

b. Fungsi Informatif

Selain menyediakan buku-buku mata kuliah, perpustakaan juga menyediakan bahan pustaka nonbuku seperti majalah, koran, kliping, buletin, dan lain-lain yang dapat digunakan sebagai bahan informasi.

c. Fungsi Tanggung Jawab Administratif

Fungsi ini dapat terlihat dari kegiatan seharihari di mana setiap ada pengembalian dan peminjaman buku, selalu dicatat oleh pustakawan. Setiap mahasiswa yang akan masuk ke perpustakaan harus menunjukkan kartu anggota. Apabila mahasiswa telat mengembalikan buku maka akan dikenai denda dan bila menghilangkannya harus menggantinya. Hal ini mendidik mahasiswa ke arah tanggung jawab dan membiasakan mahasiswa bersikap dan bertindak secara administratif.

d. Fungsi Riset/Penelitian

Bahan-bahan pustaka yang lengkap akan memudahkan stakeholders dalam mengumpulkan data atau keterangan yang diperlukan dalam melakukan penelitian. Stakeholders dapat mencari informasi yang ada untuk bahan penelitian sehingga penelitian dapat dilakukan sesuai dengan yang diharapkan.

e. Fungsi Rekreatif

Salah satu hiburan yang dapat dinikmati mahasiswa adalah dengan berkunjung ke perpustakaan, sebagai fungsi rekreatif perpustakaan menyediakan bacaan-bacaan yang dapat menghibur, seperti novel, komik, majalah, koran, dan lain-lain.

Kegiatan pengelolaan ruangan perpustakaan

Agar dapat memenuhi fungsinya dengan baik, maka sebaiknya perpustakaan ditempatkan dalam sebuah ruangan khusus, di mana besar ruangan bergantung kepada jumlah mahasiswa. Minimal ruangan suatu perpustakaan sebaiknya dapat menampung kurang lebih 30 mahasiswa. Kegiatan pengelolaan ruangan untuk perpustakaan yang baik, sebagai berikut.

1) Letak ruang perpustakaan sebaiknya sentral agar mudah didatangi dari berbagai arah.

2) Untuk mendapatkan ketenangan, perpustakaan letaknya jangan terlalu berdekatan dengan ruangruang yang memungkinkan terjadinya kebisingan.

3) Ruangan perpustakaan harus fleksibel, pengaturan letak barang-barang, dan pembagian ruangan harus mudah diubah-ubah.

4) Cara pengaturan perabot serta isi perpustakaan dan cara menghias ruangan dapat membuat perpustakaan lebih menarik dan membuat pengunjung merasa lebih nyaman duduk didalamnya.

5) Warna-warna perpustakaan harus harmonis, menyenangkan, membuat orang merasa tenang, dan tenteram duduk dalam perpustakaan itu. (Soedibyo, 1988:24).

Selain dari kegiatan pengelolaan ruangan perpustakaan, salah satu kegiatan utama atau jasa utama perpustakaan adalah peminjaman buku dan materi lainnya kegiatan peminjaman ini sering dikenal dengan nama sirkulasi artinya peminjaman. Bagian ini, terutama meja sirkulasi, seringkali dianggap sebagai ujung tombak jasa perpustakaan karena bagian inilah yang pertama kali berhubungan dengan pemakai serta paling sering digunakan pemakai. Karena unjuk kerja staf sirkulasi dapat berpengaruh terhadap citra perpustakaan. Kegiatan rutin perpustakaan, meliputi.

1) Mengawasi pintu masuk.

2) Pendaftaran anggota, perpanjangan keanggotaan dan pengunduran diri anggota perpustakaan.

3) Meminjamkan serta mengembalikan buku dengan memperpanjang waktu peminjaman.

4) Menarik denda bagi buku yang terlambat dikembalikan.

5) Mengeluarkan surat peringatan bagi buku yang belum dikembalikan pada waktunya.

6) Tugas yang berkaitan dengan peminjaman buku, khususnya buku hilang atau rusak.

7) Bertanggung jawab atas segala berkas peminjaman.

8) Membuat statistika peminjaman.

9) Peminjaman antarperpustakaan.

10)Mengawasi urusan penitipan tas, jas, mantel, dan sebagainya milik pengunjung perpustakaan. Tugas lainnya terutama yang berkaitan dengan peminjaman.

\section{Pengertian Kepusan Pelanggan}

Berbicara tentang kepuasan pelanggan tidak mudah didefinisikan, ada berbagai macam definisi atau pengertian kepuasan pelanggan yang diberikan oleh para pakar. Kepuasan pelanggan diartikan sebagai realisasi respon, hal tersebut merupakan penilaian terhadap produk atau karakteristik layanan pada tingkat yang sangat menyenangkan atau sangat tidak menyenangkan. Kepuasan pelanggan adalah pelanggan yang merasa puas dengan layanan dan menerima kebutuhan-kebutuhannya, keinginan, dan harapan-harapan. (Stamatis, 1997:159). Kepuasan pelanggan dijamin oleh produksi kualitas hasil atau layanan yang tinggi (Goetch, Davis, 1997:157) Kepuasan pelanggan (customer satisfaction) merupakan perpaduan antara harapan (keinginan dan Perspektif Ilmu Pendidikan - Vol.21 Th. XII April 2010

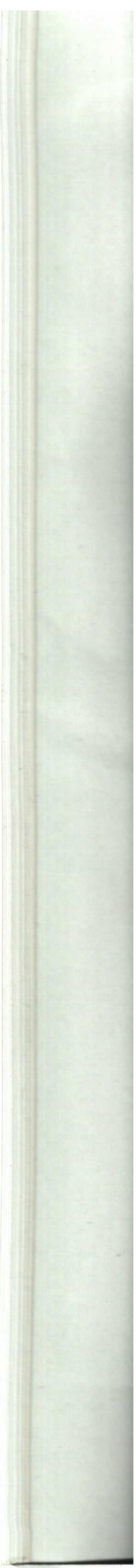


kebutuhan) pelanggan, manajemen sumber daya manusia dan operasionalisasi lembaga. (joel, 1995:207) Beberapa upaya penting yang harus diperhatikan dalam meningkatkan kepuasan pelanggan yaitu memahami adanya kebutuhan untuk berubah, menyiapkan aturan yang jelas, menyiapkan pendidikan dan latihan yang sesuai, menyiapkan sumber daya untuk memberikan tugas-tugas pekerjaan, memberikan kebebasan untuk menjadi kreatif dan inovatif, memberikan orang-orang otoritas untuk penilaian diri yang terbaik, memberi tanggung jawab orang-orang untuk perbaikan secara terus menerus, memberikan pengakuan atas apa yang dimilikinya,dan menumbuhkan rasa memiliki ( Stamatis, 1997: 140-142)

Mengacu kepada pendapat tersebut, bahwa substansi kepuasan pelanggan adalah kebutuhan akan pelanggan, hal ini didukung dengan pendapat bahwa berbicara tentang kebutuhan pelanggan sama pula membahas tentang dimensi mutu dari suatu produk atau jasa (supranoto, 2001:7), karena yang menetapkan mutu suatu lembaga adalah pelanggan. Selanjutnya, dijelaskan pula tentang dimensi kualitas yang dapat digunakan untuk menganalisis karakteristik kualitas produk, dalam hal ini produk layanan yaitu dimensi performance, features, reliability (keandalan) conformance (konformansi), durability aesthetic ,dan perceived quality ( Gasperz, 2002:33-38). Pakar lain menjelaskan pula dimensi kualitas meliputi time, timeliness, completeness, courtesy, consistency, accesility, accuracy, responsiveness (Lindays Williem, 2003: 55).

Berdasarkan uraian di atas, maka kepuasan pelanggan yang dimaksud adalah perasaan senang/ puas atau tidak senang/tidak puas terhadap layanan yang diperoleh. Layanan tersebut meliputi: layanan harapan pelanggan (mahasiswa).

Tingkatan ekspektasi harapan pelanggan

Tiga tingkatan ekspektasi (harapan) pelanggan yaitu ekspektasi dasar, spesifikasi kebutuhan, kesenangan dan kegembiraan, ketiga ekpektasi ini dikenal dengan ekspektasi implisit, ekspektasi eksplisit dan ekspektasi tersembunyi(Lindays Williem, 2003: 39).

Ekspektasi dasar dari pelanggan merupakan tingkat terendah dalam model hierarki ekspektasi pada pelanggan (level1), bila karakteristik produk itu hilang maka pelanggan akan selalu tidak puas. Ekspektasi tingkat kedua dari pelanggan mencakup spesifikasi dan kebutuhan yang terdiri dari pilihan-pilihan dan trade off yang tersedia untuk dipilih oleh pelanggan.

Pada tingkat ini, spesifikasi dan kebutuhan

Perspektif Ilmu Pendidikan - Vol.21 Th. XII April 2010 ditentukan dan dinegosiasikan antara pelanggan. Adapun ekspektasi tingkat ketiga dari pelanggan merupakan nilai tambah dari karakteristik features yang tidak diketahui sebelumnya oleh pelanggan (ekspektasi tersembunyi) sehingga bila karakteristik tersebut ada pada produk (layanan) maka pelanggan akan merasa senang.

Ketiga tingkatan ekspektasi tersebut dapat ditelaah melalui hierarki kebutuhan manusia yang dikemukakan oleh Maslow yaitu: psychological needs, and security needs, belongingness and love needs, esteem needs, and the need for self-actualization(stoner: 1978:413) Kebutuhan psikologi dasar adalah kebutuhan yang bersifat biologis, seperti kebutuhan udara, air, makanan, sex, dan lain-lain. Kebutuhan akan keamanan adalah kebutuhan yang berfungsi memberi perlindungan dari segi fisik dan emosi seperti kebutuhan akan rasa tenteram, dan bebas dari rasa takut, keamanan pribadi maupun keluarga. Kebutuhan sosial (cinta dan kasih sayang) seperti kebutuhan akan persahabatan, diakui, dan diterima oleh masyarakat lingkungannya. Kebutuhan akan penghargaan yaitu kebutuhan akan pengakuan atas status dan prestasi yang telah dicapai, sedangkan kebutuhan aktualisasi diri yaitu kebutuhan akan perwujudan diri, pencapaian pembawaan sikap dirinya terhadap tugas, dan pekerjaan yang menjadi tanggung jawabnya.

\section{METODOLOGI}

\section{Tujuan Penelitian}

Penelitian ini bertujuan untuk mengetahui pengembangan perpustakaan jurusan Manajemen Pendidikan yang ditinjau dari: pertama, ketersediaan sarana dan pemanfaatan bahan pustaka, kedua, pengelolaan perpustakaan Jurusan Manajemen Pendidikan,dan ketiga kepuasan stakeholders terhadap layanan perpustakaan Jurusan Manajemen Pendidikan.

\section{Pendekatan dan Metode Penelitian}

Pendekatan yang digunakan dalam penelitian ini adalah pendekatan survey dan analisis data sekunder dengan metode eksploratif dan deskriptif. Tempat dan Waktu Penelitian

Penelitian dilakukan di jurusan Manajemen Pendidikan FIP UNJ dan waktu yang dibutuhkan dalam penelitian ini selama empat bulan.

\section{Populasi dan Sampel}

Populasi penelitian ini adalah civitas akademika jurusan Manajemen Pendidikan yang masih aktif mengikuti perkuliahan, yakni mahasiswa angkatan 2007, 2008, dan 2009. Adapun sampel yang 
diambil dari tiap-tiap angkatan sebanyak 24 responden, sehingga total sampel sebanyak 72 responden. Sampel dilakukan dengan teknik simple random.

\section{Instrumen Penelitian}

Untuk mendapatkan informasi tentang pengembangan perpustakaan jurusan manajemen pendidikan, dilakukan melalui wawancara maupun dengan teknik paper and pencil yang dilakukan dengan penyebaran instrumen kepada para responden.

1. Definisi Objek Penelitian:

Pengembangan perpustakaan jurusan Manajemen Pendidikan merupakan kegiatan yang dilakukan dalam rangka memberikan layanan perpustakaan yang optimal kepada stakeholders yang meliputi: ketersediaan sarana dan pemanfaatan bahan pustaka, pengelolaan perpustakaan jurusan Manajemen Pendidikan, dan kepuasan stakeholders terhadap layanan perpustakaan jurusan Manajemen Pendidikan.

\section{Teknik Pengumpulan Data}

Untuk memperoleh data tentang ketersediaan sarana dan pemanfaatan bahan pustaka, pengelolaan perpustakaan jurusan Manajemen Pendidikan, dan kepuasan stakeholders terhadap layanan perpustakaan jurusan Manajemen Pendidikan digunakan angket. Selain itu, untuk mendukung keabsahan data, maka ditunjang dengan wawancara.

\section{Teknik Analisis Data}

Analisis data hasil penelitian menggunakan metode deskriptif dan metode eksploratif. metode deskriptif digunakan untuk menganalisis hasil angket dari responden tentang pengembangan perpustakaan jurusan Manajemen Pendidikan yang ditinjau dari ketersediaan sarana dan pemanfaatan bahan pustaka, pengelolaan perpustakaan jurusan Manajemen Pendidikan, dan kepuasan stakeholders terhadap layanan perpustakaan jurusan Manajemen Pendidikan. Metode eksploratif digunakan untuk menganalisis hasil wawancara dari responden tentang pengembangan perpustakaan secara ideal. Dari analisis tersebut akan dimunculkan sebuah kesimpulan mengenai harapan mahasiswa terhadap layanan perpustakaan yang selanjutnya seluruh stakeholders dapat berkontribusi mengembangkan perpustakaan jurusan menjadi lebih tertata dan nyaman untuk dikunjungi.

\section{PEMBAHASAN}

\section{Deskripsi Objek Penelitian}

Penelitian ini dilakukan pada perpustakaan di jurusan Manajemen Pendidikan FIP UNJ. Adapun visi dan misi perpustakaan jurusan Manajemen Pendidikan adalah:

Visi:

Menjadikan perpustakaan jurusan manajemen pendidikan sebagai pusat pengembangan pendidikan yang berbasis teknologi informasi dan komunikasi (TIK)

Misi:

1. Mengembangkan bahan koleksi perpustakaan menyediakan sarana pendukung perpustakaan berbasis teknologi informasi dan komunikasi (TIK) 2. Memberikan layanan prima kepada stakeholders.

Visi dan misi di atas sesuai dengan semangat undang-undang perpustakaan Nomor 43 Tahun 2007 bahwa perpustakaan perguruan tinggi mengembangkan layanan perpustakaan berbasis teknologi informasi dan komunikasi.

Ditinjau dari awal pembentukan perpustakaan jurusan Manajemen Pendidikan, keberadaan perpustakaan jurusan Manajemen Pendidikan mulai dirintis pada tahun 2003 dengan menggunakan salah satu ruangan yang berdekatan dengan ruang dosen jurusan manajemen pendidikan. Adapun koleksi bahan pustaka, diperoleh dari berbagai sumber, yakni dari sumbangan para dosen dan juga bantuan dari pemerintah. Sampai saat ini jumlah koleksi yang dimiliki perpustakaan jurusan Manajemen Pendidikan baru mencapai \pm 700 bahan pustaka, yang terdiri dari buku-buku yang terkait dengan keilmuan manajemen pendidikan, maupun buku-buku umum dan keagamaan, kumpulan laporan hasil magang dan PPL mahasiswa, laporan hasil observasi perkuliahan, kumpulan hasil penelitian dosen-dosen manajemen pendidikan dan kumpulan skripsi mahasiswa. Pada perjalanannya, perpustakaan belum dikelola secara optimal, buku-buku belum terkatalogisasi secara baik dan belum berbasis web.

Mengingat keberadaan perpustakaan ini sangat penting dalam menunjang kualitas pembelajaran, maka pada tahun 2009 ini akan dikembangkan perpustakaan berbasis web terutama dalam hal pengembangan katalogisasi bahan pustaka dan pencarian bahan pustaka. Diharapkan dengan dikembangkannya perpustakaan, baik dalam aspek ketersediaan sarana dan pemanfaatan bahan pustaka, dan pengelolaan perpustakaan jurusan Manajemen Pendidikan, dapat meningkatkan kepuasan stakeholders terhadap layanan perpustakaan jurusan Manajemen Pendidikan.

Deskripsi Data

1. Pengelolaan perpustakaan jurusan manajemen Perspektif llmu Pendidikan - Vol.21 Th. XII April 2010 
pendidikan.

Pada aspek pengelolaan perpustakaan, indikator yang dinilai adalah kelengkapan bahan pustaka, pelayanan perpustakaan, dan kerapihan serta perawatan perpustakaan. Dari 72 responden, $62.5 \%$ menjawab bahwa bahan pustaka yang ada di jurusan belum sesuai dengan kebutuhan mahasiswa. Data tersebut dapat divisualisasikan pada gambar berikut.

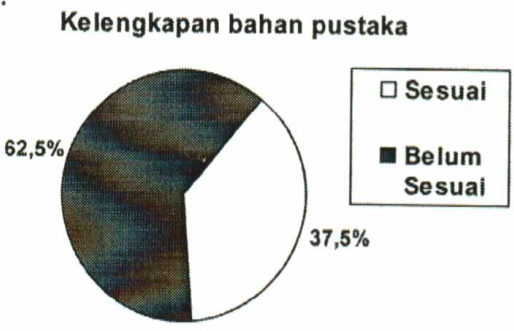

Gambar 1. Persentase Kelengkapan Bahan Pustaka

Ini menunjukkan bahwa bahan pustaka di jurusan Manajemen Pendidikan, baik ketersediaan buku-buku manajemen pendidikan, ketersediaan surat kabar dan majalah, maupun ketersediaan buku fiksi dan nonfiksi belum lengkap.

Pelayanan perpustakaan yang diberikan cukup memuaskan, yakni 76,4\% menjawab bahwa pengelola perpustakaan melayani dengan ramah di samping mahasiswa juga dapat meminjam buku dengan terlebih dahulu menunjukkan kartu anggota perpustakaan. Data tersebut dapat divisualisasikan pada gambar berikut.

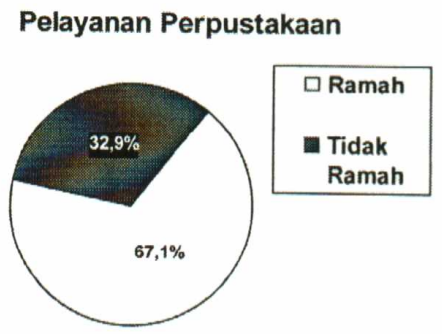

Gambar 2. Persentase Pelayanan Perpustakaan

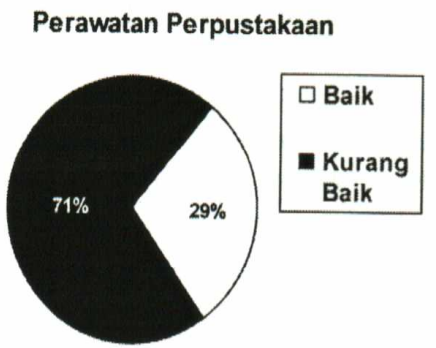

Gambar 3. Persentase Perawatan Perpustakaan
2. Ketersediaan sarana dan pemanfaatan bahan pustaka

Pada aspek ketersediaan sarana dan pemanfaatan bahan pustaka, terdapat dua indikator yang dinilai, yaitu ketersediaan fasilitas serta pemanfaatan perpustakaan dan bahan pustaka. Pada aspek ketersediaan fasilitas perpustakaan, sebanyak $95.8 \%$ responden menjawab ruang perpustakaan sudah dilengkapi dengan AC dan komputer, meskipun ruangan tidak terlalu luas dan fasilitas komputer yang ada belum dapat digunakan untuk pencarian buku, Data tersebut dapat divisualisasikan pada gambar berikut:

ketersediaan fasilitas perpustakaan

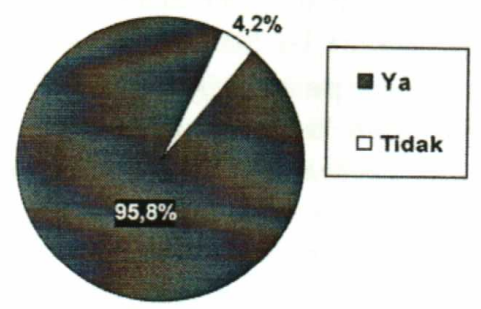

Gambar 4. Persentase Pemanfaatan Perpustakaan

Terkait pemanfaatan perpustakaan, $68 \%$ mahasiswa tidak memanfaatkan perpustakaan di waktu senggang, meskipun perpustakaan buka setiap hari. Alasannya disebabkan karena ruang perpustakaan sempit dan buku belum tertata dengan rapi. Data tersebut dapat divisualisasikan pada gambar berikut.

Terkait pemanfaatan perpustakaan, $68 \%$ mahasiswa tidak memanfaatkan perpustakaan di waktu senggang, meskipun perpustakaan buka setiap hari. Alasannya disebabkan karena ruang perpustakaan sempit dan buku belum tertata dengan rapi. Data tersebut dapat divisualisasikan pada gambar berikut:

Pemanfaatan Perpustakaan

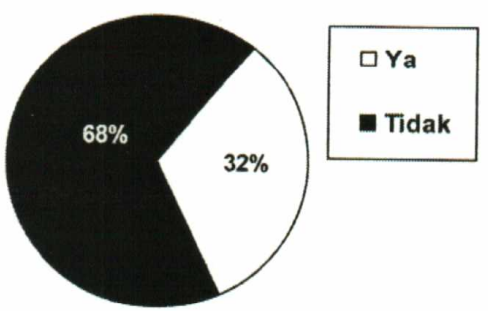

Gambar 5. Persentase Pemanfaatan Perpustakaan

Dalam hal pemanfaatan bahan pustaka, sedikit sekali mahasiswa yang memanfaatkan bahan pustaka yang ada di jurusan, ini disebabkan karena sulitnya menemukan buku yang dicari, terdapat $70.8 \%$ 
responden menjawab tidak mudah menemukan buku yang dicari. Data tersebut dapat divisualisasikan pada gambar berikut:

\section{Kemudahan Pencarian Buku}

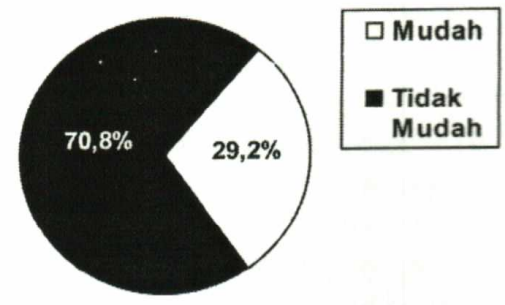

Gambar 6. Persentase Kemudahan Pencarian Buku

3. Kepuasan stakeholders terhadap layanas perpustakaan jurusan Manajemen Pendidikan.

Pada aspek kepuasan, indikator yang dinilai adalah kepuasan pelayanan serta kepuasan kelengkapan bahan pustaka. Dalam hal kepuasan pelayanan, sebanyak $98,6 \%$ responden menjawab belum puas terhadap layanan yang diberikan. Data tersebut dapat divisualisasikan pada gambar berikut:

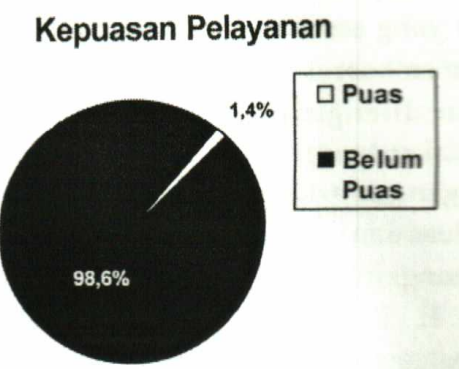

Gambar 7. Persentase Kepuasan Pelayanan

Adapun dalam hal kepuasan kelengkapan bahan pustaka, sebanyak $100 \%$ responden belum puas dengan kelengkapan bahan pustaka, dalam arti bahan pustaka yang tersedia, belum lengkap dan belum terkatalogisasi dengan baik. Data tersebut dapat divisualisasikan pada gambar berikut:
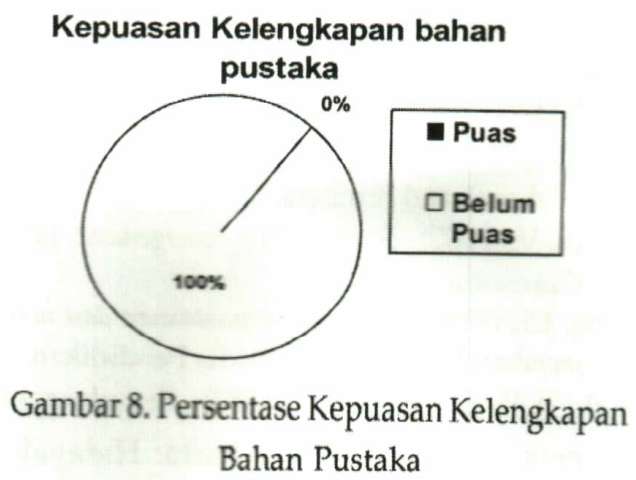

Jawaban yang diberikan oleh responden terkait kontribusi yang dapat diberikan dalam upaya pengembangan perpustakaan jurusan yakni $64 \%$ responden setuju jika mahasiswa yang akan lulus menyumbangkan satu buah buku ke perpustakaan jurusan. Data tersebut dapat divisualisasikan pada gambar berikut:

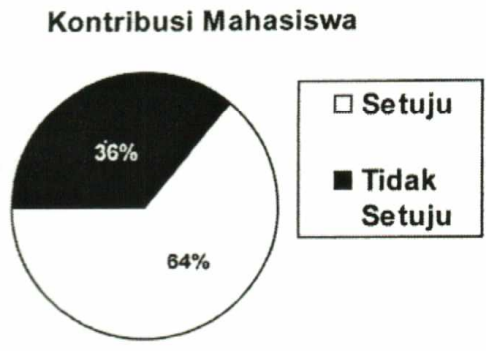

Gambar 9. Persentase Kontribusi Mahasiswa

\section{Analisis Data}

Pada aspek pengelolaan perpustakaan, baik dilihat dari kelengkapan bahan pustaka, pelayanan perpustakaan, dan kerapihan serta, perawatan perpustakaan masih perlu dilengkapi dan perbaiki. Ini terlihat dari jawaban responden di mana $62.5 \%$ mengatakan bahwa bahan pustaka yang ada di jurusan belum dapat memenuhi kebutuhan perkuliahan mahasiswa. Ini menunjukkan bahwa bahan pustaka di jurusan Manajemen Pendidikan, baik ketersediaan buku-buku manajemen pendidikan, ketersediaan surat kabar dan majalah, maupun ketersediaan buku fiksi dan nonfiksi belum lengkap sehingga perlu ada penambahan koleksi bahan pustaka yang sesuai dengan kebutuhan pengguna.

Pelayanan perpustakaan yang diberikan sudah cukup memuaskan, yakni dengan melihat jawaban responden, sebanyak $76,4 \%$ mengatakan bahwa pengelola perpustakaan sudah melayani dengan ramah. Maka dari itu, pelayanan yang mengarah kepada kepuasan pelanggan (custumor satisfaction) perlu dipertahankan bahkan ditingkatkan.

Bahan pustaka yang ada belum tertata dengan baik, ini dilihat dari jawaban responden sebanyak $71 \%$ menjawab buku di perpustakaan jurusan belum tertata dengan rapi dan mayoritas dalam keadaan kurang baik. Ini disebabkan tidak tersedianya tenaga yang khusus mengelola perpustakaan, karena dari awal berdiri, mahasiswalah yang ditugasi untuk pengelolaannya dan pada tahun 2006/2007 sekelompok mahasiswa mulai mengkatalogisasikan buku secara rapi, tetapi belum dapat diakses melalui komputer, sehingga pencarian masih bersifat manual. Maka dari itu, perlu adanya pengkatalogisasian dan Perspektif Ilmu Pendidikan - Vol.21 Th. XII April 2010 
penataan kembali agar dapat tersusun rapi dan mudah ditemukan.

Jika dilihat, fasilitas yang dimiliki perpustakaan sudah cukup lengkap, yakni terdapat meja dan kursi, AC, komputer, dan rak buku. Hanya saja ruangannya tidak terlalu luas, sehingga syarat minimal sebuah perpustakaan yang dapat merampung sedikitnya 30 orang tidak terpenuhi. Dampak nyatanya adalah mahasiswa tidak memanfaatkan perpustakaan secara optimal. Jarang mahasiswa yang datang mengunjungi perpustakaan untuk membaca buku, kalaupun ada, hanya sebagian kecil saja dan itu hanya sekedar untuk beristirahat.

Strategi yang dapat digunakan untuk menarik minat mahasiswa mengunjungi perputakaan yaitu dengan membuat alat pencari buku yang terkomputerisasi serta dilengkapi dengan barcode sehingga mahasiswa mudah menemukan buku yang dicari, di samping memudahkan pengelola perpustakaan dalam sirkulasi peminjaman buku. Selain itu, dapat juga dilakukan dengan mendesain ruangan sedemikian rupa sehingga terlihat luas dan mahasiswa nyaman di dalamnya atau jika dimungkinkan dapat mengusulkan ke Pembantu Dekan II Fakultas Ilmu Pendidikan untuk penambahan atau perluasan ruangan.

Dalam hal kepuasan pelayanan, sebanyak $98,6 \%$ responden menjawab belum puas terhadap layanan yang diberikan maupun kelengkapan bahan pustaka. Ini dikarenakan belum berfungsinya perpustakaan dengan baik, belum adanya tenaga khusus yang mengelola perpustakaan sehingga sirkulasi peminjaman buku belum berjalan baik, serta pencarian buku belum terkomputerisasi dan belum ditata rapi. Maka dari itu, pelayanan perpustakaan jurusan perlu lebih ditingkatkan dengan menyediakan tenaga khusus pengelola perpustakaan, dengan menambah bahan pustaka yang lebih up to date dan relevan dengan disiplin ilmu manajemen pendidikan.

Untuk menambah bahan pustaka yang up to date dapat pula melibatkan mahasiswa sebagai kontribusi nyata mereka kepada jurusan, yakni mahasiswa yang akan lulus menyumbangkan satu buah buku ke perpustakaan jurusan. Bahkan setelah melakukan wawancara dengan beberapa resonden, inisiatif mahasiswa yang tergabung dalam HIMA MP sudah mengumpulkan buku dari mahasiswa baru angkatan 2009 pada saat Masa Pengenalan Akademik (MPA), saat ini buku berada di perpustakaan HIMA dan mereka ingin menyumbangkan buku-buku tersebut ke perpustakaan jurusan manajemen pendidikan jika perpustakaan sudah terkelola dengan baik.

\section{PENUTUPAN}

\section{Kesimpulan}

Berdasarkan hasil penelitian yang telah dilakukan, maka dapat ditarik beberapa kesimpulan sebagai berikut (1) perpustakaan jurusan Manajemen Pendidikan belum terkelola dengan baik, ini dapat dilihat dari ketersediaan koleksi bahan pustaka yang belum lengkap, belum ada tenaga khusus pengelola perpustakaan, dan sebagian besar bahan pustaka belum tertata dengan rapi dan mayoritas dalam keadaan kurang baik; (2) ketersediaan sarana sudah cukup lengkap hanya saja ruangannya tidak terlalu luas sehingga hanya dapat menampung kurang lebih 20 mahasiswa. Dampak nyatanya adalah mahasiswa tidak memanfaatkan perpustakaan secara optimal; serta (3) kepuasan pelanggan terhadap layanan yang diberikan maupun kelengkapan bahan pustaka masih rendah.

Saran

Beberapa saran yang dapat diajukan dalam penelitian ini adalah (1) perpustakaan perlu dikelola dengan baik, yakni dengan menambah koleksi bahan pustaka yang sesuai dengan kebutuhan pengguna, dengan membuat alat pencari buku yang terkomputerisasi dan dilengkapi dengan barcode, dan juga menyediakan tenaga khusus pengelola perpustakaan; (2) ruangan perlu didesain sedemikian rupa sehingga terlihat luas dan mahasiswa nyaman di dalamnya atau jika dimungkinkan dapat mengusulkan ke Pembantu Dekan II Fakultas Ilmu Pendidikan untuk penambahan/perluasan ruangan; serta (3) pelayanan perpustakaan jurusan perlu lebih ditingkatkan dan dikembangkan lebih lanjut diantaranya dengan penambahan bahan pustaka yang lebih up to date dan relevan dengan disiplin ilmu Manajemen Pendidikan.

\section{DAFTAR PUSTAKA}

Bafadol, I. (2001). Pengelolaan perpustaknan sekolah. Jakarta: Bumi Aksara.

Basuki, S. (1993). Pengantar ilmu perpustakaan. Jakarta: Universitas Terbuka.

Roes, J.A. (1995). Total quality management. Singapore: Mubarok and Brothers.

Gasperz, V. (2002). Total quality management. Jakarta: Gramedia.

Porang, I.S. (1990). Peranan perpustakaan dan manfant membaca buku. Jakarta: Media Pendidikan.

Shaleh, A.R. \& Ahmad, I. (1987). Penyelenggaraan perpustakaan sekolah. Jakarta: Hidayakarta 
Agung.

Soeatminah. (1991). Perpustakaan, kepustakawanan, dan pustakawan. Yogyakarta: Kanisius.

Soedibyo, N. (1988). Pengelolaan perpustakaan. Bandung: Alumni.

Stamatis, D.H. (1997). Total quality service. New Delhi: Vanity Book International.

Stanly, L. G., \& Davis, B. (1997). Introduction to total quality. New Jersey: Prentice Hall.

Stoner, J.A.F. (1978). Management. USA: Prentice Hall.Inc.

Sumadji, P. (1992). Perpustakaan: Organisasi dan tata kerjanya. Yogyakarta: Kanisius.

Supranto. (2001). Pengukuran tingkat kepuasan pelanggan. Jakarta: Rineka Cipta.

Williem, L.M. \& Petrick. (1997). Total quality management and organization development. Florida: St. Lucia Press.

\section{KETERANGAN PENULIS}

Rugaiyah. Lahir pada tanggal 26 Februari 1964. Saat ini aktif sebagai dosen jurusan Manajemen Fakultas Ilmu Pendidikan Universitas Negeri Jakarta. 